\title{
Toxicity of Fungicides to Urediniospores of Six Rust Fungi That Occur on Ornamental Crops
}

\author{
D. S. Mueller, Department of Plant Pathology, University of Georgia, Georgia Station, Griffin 30223; S. N. Jeffers, \\ Department of Entomology, Soils, and Plant Sciences, Clemson University, Clemson, SC 29634; and J. W. Buck, \\ Department of Plant Pathology, University of Georgia, Georgia Station, Griffin 30223
}

\begin{abstract}
Mueller, D. S., Jeffers, S. N., and Buck, J. W. 2005. Toxicity of fungicides to urediniospores of six rust fungi that occur on ornamental crops. Plant Dis. 89:255-261.

The recent introduction and rapid spread of rust on daylilies, caused by Puccinia hemerocallidis, suggested a need for fungicide treatments that reduce urediniospore viability on plant surfaces. Twelve fungicides in seven chemical classes were evaluated in vitro for toxicity to urediniospores of rust fungi that occur on daylily ( $P$. hemerocallidis), geranium ( $P$. pelargonii-zonalis), iris (P. iridis), oxalis (P. oxalis), mint (P. menthae), and Florida azalea (Pucciniastrum vaccinii). Germination of urediniospores of all six rust fungi on potato dextrose agar in the absence of fungicides ranged from 54 to $88 \%$. Germination of urediniospores of all rust species during and after exposure to azoxystrobin, chlorothalonil, copper sulfate pentahydrate, mancozeb, and trifloxystrobin was less than or near $1 \%$. Germination during exposure to fenhexamid, iprodione, myclobutanil, propiconazole, thiophanate-methyl, triadimefon, and triflumizole ranged from 0 to $60 \%$ and usually was greater ( 0 to $75 \%$ ) after fungicide residues had been removed. Germination of urediniospores of P. pelargonii-zonalis decreased when exposed to azoxystrobin, copper sulfate pentahydrate, and mancozeb for $1 \mathrm{~min}$ and was nearly eliminated after a 30-min exposure, while exposure to trifloxystrobin and chlorothalonil eliminated germination after 4 and $8 \mathrm{~h}$, respectively. Urediniospores that had been allowed to imbibe water for $4 \mathrm{~h}$ had no further germination or germ tube growth after a 24-h exposure to azoxystrobin, chlorothalonil, copper sulfate pentahydrate, mancozeb, and trifloxystrobin. Less than one lesion per plant developed on seedlings inoculated with urediniospores of $P$. pelargonii-zonalis that had been sprayed with azoxystrobin, chlorothalonil, copper sulfate pentahydrate, and mancozeb, whereas seedlings inoculated with spores not exposed to fungicides developed 148 lesions per plant. The strobilurin (azoxystrobin and trifloxystrobin), broad-spectrum protectant (chlorothalonil and mancozeb), and inorganic copper (copper sulfate pentahydrate) fungicides were fungicidal to urediniospores of the six rust fungi. However, the benzimidazole (thiophanate-methyl), dicarboximide (iprodione), hydroxyanilide (fenhexamid), and demethylation-inhibiting (myclobutanil, propiconazole, triadimefon, and triflumizole) fungicides were only fungistatic to rust urediniospores.
\end{abstract}

Rusts affect many different ornamental crops, including annuals, herbaceous perennials, shrubs, and trees (10). These diseases, although easily recognized, are among the most threatening diseases to the production and cultivation of ornamental crops because there are not adequate methods for detecting the pathogens on symptomless plants that are infested or infected. These plants may be coming into the United States from production facilities located outside the country or moving state-to-state among production, wholesale, and retail operations (21). In addition, many rust fungi use alternate hosts to

Corresponding author: J. W. Buck

E-mail: jbuck@griffin.uga.edu

Current address of D. S. Mueller: Department of Plant Pathology, Iowa State University, Ames, IA 50011.

Accepted for publication 8 October 2004.

DOI: 10.1094/PD-89-0255

(C) 2005 The American Phytopathological Society potential to cause large economic losses to many different ornamental crops due to reductions in plant health and aesthetic value and to possible quarantine restrictions and eradication efforts.

Integrated disease management provides the most effective and consistent control of diseases of ornamental crops over time (16). Fungicides usually are an important component in any integrated disease manageand plants used to maintain fungi in a greenhouse ment program, and a number of fungicides in several different chemical classes are registered for and effective against rusts on ornamental crops (15). However, little research has been done to determine the direct toxic effect of these fungicides to urediniospores in active lesions or on leaf surfaces.

Applications of fungicides for the sole purpose of reducing or eliminating spores on plant surfaces would be beneficial in several situations. For example, if plants or propagation materials (e.g., liners, cuttings, etc.) were shipped from a nursery or production facility where a specific rust was known or suspected to be present, a fungicide application immediately before or after shipping could reduce or eliminate inoculum on the plants. Also, if an effective fungicide were available, it could be applied routinely to plants to eliminate the possibility of introducing inocula of pathogens of quarantine significance. There currently are 16 pathogens in the class Basidiomycetes and order Uredinales on the Regulated Plant Pest List for the United States (22). These include eight rust pathogens of ornamental crops: chrysanthemum white rust, Puccinia horiana; Rhododendron rust, Chrysomyxa ledi; and six gladiolus rust pathogens, $P$. gladioli, P. mccleanii, Uredo gladiolibuettneri, Uromyces gladioli, U. nyikensis, and $U$. transversalis. Therefore, the objective of this study was to determine the direct toxic effect of fungicides labeled for use on ornamental crops to urediniospores of rusts that occur on these crops.

\section{MATERIALS AND METHODS}

Rust pathogens. Six rust fungi were selected for this study: five species of Puccinia and one species of Pucciniastrum (Table 1). They were recovered from naturally infected plants growing in Georgia and South Carolina. Each pathogen was

Table 1. Rust pathogens used in this study: Host plants and locations from which pathogens originated

\begin{tabular}{|c|c|c|c|}
\hline \multirow[b]{2}{*}{ Pathogen } & \multicolumn{2}{|c|}{ Original source of pathogen } & \multirow[b]{2}{*}{ Greenhouse host plant } \\
\hline & Host plant & Location & \\
\hline Puccinia hemerocallidis & Daylily & McDuffie Co., GA & Hemerocallis 'Pardon Me' \\
\hline$P$. iridis & Iris & Berkeley Co., SC & Iris 'Sinfonietta' \\
\hline P. menthae & Spearmint & Pickens Co., SC & Mentha spicata \\
\hline P. oxalis & Violet wood-sorrel & Spalding Co., GA & Oxalis violacea \\
\hline P. pelargonii-zonalis & Zonal geranium & Beaufort Co., SC & $\begin{array}{l}\text { Pelargonium } \times \text { hortorum } \\
\text { 'Elite White' }\end{array}$ \\
\hline Pucciniastrum vaccinii & Florida azalea & Fayette Co., GA & $\begin{array}{l}\text { Rhododendron austrinum } \\
\text { 'Escatawpa' }\end{array}$ \\
\hline
\end{tabular}


maintained on a suitable host plant (Table 1) in a greenhouse in Griffin, GA, with average night and day temperatures of 23 and $26^{\circ} \mathrm{C}$, respectively, except $P$. pelargonii-zonalis, which was maintained in a greenhouse with average night and day temperatures of 19 and $23^{\circ} \mathrm{C}$, respectively. For each experiment, urediniospores were collected separately from three daylily, geranium, iris, and oxalis plants for use as three replications. Urediniospores from azalea and mint were collected from three individual branches from the same plant and kept separate for use as three replications. Spores were collected by vacuum and used the same day. Urediniospores of each fungus were suspended in sterile $0.05 \%$ Tween 20 (J. T. Baker, Phillipsburg, $\mathrm{NJ})$ at two concentrations: $1 \times 10^{5}$ and $5 \times$ $10^{5}$ urediniospores per milliliter.

Fungicide toxicity experiments. Four experiments were conducted, three in the laboratory and one in the greenhouse, to determine if exposure to fungicides prevented germination of urediniospores and, if so, resulted in death or just fungistasis. Twelve fungicides currently registered for use on ornamental crops were evaluated, and all but two of these were recommended for rust management on current product labels (Table 2). Fungicides, at rates specified on product labels, were added to Difco potato dextrose agar (PDA; Becton, Dickinson, and Co., Franklin Lakes, NJ) after it had been autoclaved and cooled to approximately $50^{\circ} \mathrm{C}$.

Experiment 1: Toxicity during and after fungicide exposure. An experiment was conducted to determine the toxicity to urediniospores of all 12 fungicides both during and after direct exposure. To determine toxicity during exposure, a volume of $50 \mu$ of spore suspension $\left(1 \times 10^{5}\right.$ urediniospores per milliliter) from each fungus was pipetted directly onto PDA amended with each of the 12 fungicides, plates were placed at $22^{\circ} \mathrm{C}$ in the dark for $24 \mathrm{~h}$, germi- nation of a minimum of 150 urediniospores per replicate was determined microscopically $(\times 200)$, and percent germination was calculated. Three replicate plates were used for each combination of pathogen and fungicide. To determine toxicity after fungicide exposure, a 200- $\mu$ l aliquot of spore suspension $\left(5 \times 10^{5}\right.$ urediniospores per milliliter) was pipetted onto a sterile 25mm-diameter filter $(0.03 \mu \mathrm{m}$, Type $\mathrm{PH}$; Millipore Corporation, Bedford, MA) on the surface of each plate of fungicideamended PDA, and plates were placed at $22^{\circ} \mathrm{C}$ in the dark for $24 \mathrm{~h}$. Filters were removed and urediniospores were washed from the filters with $0.05 \%$ Tween 20 solution and resuspended in $12 \mathrm{ml}$ of $0.05 \%$ Tween 20 solution. Suspensions were centrifuged $(1,000 \times g)$ for $2 \mathrm{~min}$, and the supernatant was discarded. This wash procedure was conducted three times to remove fungicide residues from urediniospores. Aliquots of $50 \mu \mathrm{l}$ of each washed spore suspension were pipetted onto PDA amended with chloramphenicol (CPDA; Sigma-Aldrich Co., St. Louis, MO) at 100 $\mu \mathrm{g} \mathrm{ml}{ }^{-1}$, plates were placed in the dark at $22^{\circ} \mathrm{C}$ for $18 \mathrm{~h}$, and then germination of a minimum of 150 urediniospores per replicate was determined microscopically. The experiment was conducted twice.

Experiment 2: Effect of exposure time on toxicity. The effect of exposure time on toxicity was investigated using five of the more potent fungicides (based on results in experiment 1): the two strobilurins (azoxystrobin and trifloxystrobin), the two broad-spectrum protectants (chlorothalonil and mancozeb), and the inorganic copper compound (copper sulfate pentahydrate). Aliquots $(200 \mu \mathrm{l})$ of suspensions of urediniospores of $P$. pelargonii-zonalis $\left(5 \times 10^{5}\right.$ urediniospores per milliliter) were pipetted onto sterile 25-mm-diameter Millipore filters on the surface of CPDA amended with each of the five fungicides (18 plates per fungicide, 90 plates total). Aliquots (50 $\mu \mathrm{l})$ of each spore suspension also were pipetted directly onto CPDA at the start of the experiment to determine germination in the absence of fungicide. Plates were placed in the dark at $22^{\circ} \mathrm{C}$, and spores were exposed to fungicide-amended medium for six time durations: $1 \mathrm{~min}, 30 \mathrm{~min}$, $1 \mathrm{~h}, 2 \mathrm{~h}, 4 \mathrm{~h}$, and $8 \mathrm{~h}$. Filters on three replicate plates were removed after each duration, and urediniospores were washed from filters by centrifugation in $0.05 \%$ Tween 20 solution. Germination was assessed as described above in experiment 1 , and germ tube lengths were measured $(\times 200)$ for the first 25 spores that had initiated germination. The experiment was conducted twice.

Experiment 3: Toxicity of fungicides to germinated spores. The toxicity of fungicides to germinated urediniospores was determined for the five fungicides used in experiment 2: azoxystrobin, chlorothalonil, copper sulfate pentahydrate, mancozeb, and trifloxystrobin. Aliquots $(200 \mu \mathrm{l})$ of spore suspensions $(5 \times$ $10^{5}$ urediniospores per milliliter) of $P$. hemerocallidis, $P$. pelargonii-zonalis, and $P$. iridis were pipetted onto sterile Millipore filters on the surface of $1.5 \%$ water agar (WA) plates. Plates were held for $4 \mathrm{~h}$ at $22^{\circ} \mathrm{C}$ in the dark to initiate germination; the filters with urediniospores then were transferred to plates of CPDA amended with each of the five fungicides and a nonamended control. After the initial $4 \mathrm{~h}$ on WA, germination was determined from a minimum of 150 spores per replicate, and lengths of germ tubes were measured for the first 25 spores that had germinated. After $24 \mathrm{~h}$ on fungicide-amended CPDA, urediniospores were washed from filters and germination and germ tube lengths were assessed as described above. The germination and germ tube lengths of urediniospores after exposure to fungicides were compared with germination and germ tube lengths of urediniospores after $4 \mathrm{~h}$ on WA. The experiment was conducted twice.

Table 2. Fungicides registered for use on ornamental crops that were evaluated for toxicity to urediniospores of six rusts that occur on ornamental crops

\begin{tabular}{|c|c|c|c|c|c|}
\hline Fungicide category & Active ingredient & Trade name & Formulation ${ }^{\mathrm{u}}$ & Rate (amount/liter) ${ }^{v}$ & Labeled for rust $^{\mathrm{w}}$ \\
\hline \multirow[t]{3}{*}{$\mathrm{DMI}^{\mathrm{x}}$ triazole } & Myclobutanil & Systhane & $40 \mathrm{WP}$ & $300 \mathrm{mg}$ & Yes \\
\hline & Propiconazole & Banner MAXX & 14.3 MEC & $400 \mu \mathrm{l}$ & Yes $y$ \\
\hline & Triadimefon & Strike & $25 \mathrm{WP}$ & $300 \mathrm{mg}$ & Yes \\
\hline DMI $^{\mathrm{x}}$ imidazole & Triflumizole & Terraguard & $50 \mathrm{WP}$ & $600 \mathrm{mg}$ & Yes \\
\hline \multirow{2}{*}{ Strobilurin } & Azoxystrobin ${ }^{z}$ & Heritage & $50 \mathrm{WDG}$ & $300 \mathrm{mg}$ & Yes \\
\hline & Trifloxystrobin ${ }^{z}$ & Compass & $50 \mathrm{WDG}$ & $300 \mathrm{mg}$ & Yes \\
\hline Dicarboximide & Iprodione & Chipco 26019 & $50 \mathrm{WP}$ & $1,200 \mathrm{mg}$ & No \\
\hline Benzimidazole & Thiophanate-methyl & 3336 & $50 \mathrm{WP}$ & $1,200 \mathrm{mg}$ & Yes \\
\hline Hydroxyanilide & Fenhexamid & Decree & $50 \mathrm{WDG}$ & $1,200 \mathrm{mg}$ & No \\
\hline \multirow[t]{2}{*}{ Broad-spectrum } & Chlorothalonil & Daconil Ultrex & 82.5 WDG & $1,700 \mathrm{mg}$ & Yes \\
\hline & Mancozeb & Dithane $\mathrm{T} / \mathrm{O}$ & 75 WDG & $1,800 \mathrm{mg}$ & Yes \\
\hline Inorganic copper & Copper sulfate pentahydrate & Phyton 27 & $21.4 \mathrm{SC}$ & $4,000 \mu \mathrm{l}$ & Yes \\
\hline
\end{tabular}

" Percentages of active ingredients in commercial products formulated as wettable powders (WP), a microemulsion concentrate (MEC), water dispersible granules (WDG), or a soluble concentrate (SC).

$\checkmark$ Amount of commercial product used in all experiments; rates are those recommended on product labels.

${ }^{\mathrm{w}}$ Fungicide is recommended for management of at least some rusts on the 2003 product label.

${ }^{x}$ Demethylation inhibitors of sterol biosynthesis.

y Propiconazole should not be applied to Pelargonium spp. according to label specifications.

${ }^{\mathrm{z}}$ Salicylhydroxamic acid (SHAM, $100 \mathrm{mg} /$ liter) was added to the azoxystrobin- and trifloxystrobin-amended potato dextrose agar to inhibit the alternative oxidase respiratory pathway. 
Experiment 4: Pathogenic potential of spores after exposure to fungicides. The pathogenic potential of spores of $P$. pelargonii-zonalis that had been exposed to fungicides was evaluated on geranium seedlings. Dry urediniospores were transferred to sterile 25-mm-diameter filters and sprayed with water (control) or with label rates (Table 2) of eight fungicides: azoxystrobin, chlorothalonil, copper sulfate pentahydrate, iprodione, mancozeb, myclobutanil, propiconazole, and triadimefon. After $48 \mathrm{~h}$ at $22^{\circ} \mathrm{C}$ in the dark, urediniospores were washed from the filters and resuspended in $0.05 \%$ Tween 20 as described above. Viability of spores exposed to fungicides was determined by pipetting a $50-\mu \mathrm{l}$ aliquot of each spore suspension onto CPDA and assessing germination as described above. The remainder of each spore suspension (i.e., approximately $2 \mathrm{ml}$ at 1 to $2 \times 10^{5}$ spores per milliliter) was misted onto 12-week-old geranium seedlings (cv. Elite White). For each fungicide treatment, three replications with six plants per replication were used. The plants were held at $20^{\circ} \mathrm{C}$ and $100 \%$ relative humidity in the dark for $24 \mathrm{~h}$ to promote infection and then were moved to a greenhouse (average night and day temperatures of 19 and $21^{\circ} \mathrm{C}$, respectively) to allow pathogenesis to progress and lesions to develop. The number of lesions on each plant was counted 18 days after inoculation. In all, 18 plants were used for each treatment and 162 plants $(9$ treatments $\times 18$ plants/ treatment) were used for each trial of the experiment. The experiment was conducted twice.

Statistical analyses. In each experiment, data for each rust fungus were analyzed independently because all fungi could not be evaluated simultaneously and comparisons among fungi were not the highest priority. Treatments in all experiments were analyzed by analysis of variance (ANOVA) using the general linear models procedure (PROC GLM) of SAS, version 8.02 (SAS Institute Inc., Cary, NC). For each experiment, repetitions and replications were considered random variables, and treatments were considered a fixed variable. In all experiments, preliminary analyses were conducted to evaluate the effect of trials and trial $\times$ treatment interactions to determine if data from separate trials could be combined.

Treatments in the first experiment were analyzed by two-way ANOVA with fungicides and fungicide exposure method as factors. Individual fungicide means were compared in single-degree-of-freedom contrasts, and differences between exposure methods were compared with Fisher's protected least significant difference (LSD) with $P=0.05$. In experiment 2 , data were analyzed by two-way ANOVA with fungicide and exposure time as main effects, and treatment means were separated by $\operatorname{LSD}(P=0.05)$. In experiment 3 , dif- ferences among fungicides for both percent germination and germ tube length were analyzed by one-way ANOVA, and germination and germ tube length of urediniospores after exposure to fungicides were compared with germination and germ tube length of urediniospores after $4 \mathrm{~h}$ on WA using single-degree-of-freedom contrasts. In experiment 4, using geranium seedlings, data from the six plants within each replication were averaged, and these averages were analyzed by one-way ANOVA; treatment means were separated by LSD $(P=0.05)$. In addition, Pearson's correlation coefficient was calculated using the SAS Pearson correlation procedure (PROC CORR) to determine the relationship among the results from several experiments. A correlation of percent germination of urediniospores of $P$. pelargoniizonalis after exposure to fungicides on agar medium (experiment 1 ) and by direct spray (experiment 4) was determined, and a correlation of percent germination of urediniospores of and lesion development on geranium seedlings by $P$. pelargoniizonalis after spores were exposed to fungicides in experiment 4 was determined.

\section{RESULTS}

In each of the four experiments, data among trials were similar and the effects of trials and trial $\times$ treatment interactions were not significant $(P>0.05)$. Therefore, data for individual trials were combined for analyses in all experiments.

Experiment 1: Toxicity during and after fungicide exposure. Germination of all six of the rust fungi was affected significantly by the fungicides tested in this experiment and by the type of exposure to these fungicides (Table 3, Fig. 1). However, the effects of individual fungicides were not uniform during and after exposure to fungicide-amended PDA, as demonstrated by highly significant $(P<0.001)$ fungicide $\times$ exposure interactions in twoway ANOVAs (Table 3). Consequently, the effects on urediniospore germination during and after fungicide exposure were analyzed separately (Table 3). Of the 12 fungicides tested, azoxystrobin, trifloxystrobin, chlorothalonil, mancozeb, and copper sulfate pentahydrate eliminated or nearly eliminated germination by all six rust fungi when spores were assessed both during and after exposure to fungicideamended agar (Fig. 1), which suggested that these fungicides were lethal to urediniospores. The other seven fungicides (myclobutanil, propiconizole, triadimefon, triflumizole, iprodione, fenhexamid, and thiophanate-methyl) allowed spores of most fungi to germinate either during and after exposure or just after exposure (Fig. 1). When germination occurred, it usually was significantly less during exposure to fungicides than after spores had been removed from fungicide-amended agar and washed free of residues, suggesting that these fungicides inhibited germination of rust urediniospores but did not prevent it. Thiophanate-methyl and fenhexamid on $P$. iridis and propiconizole, triadimefon, thiophanate-methyl, and fenhexamid on Pucciniastrum vaccinii were the only exceptions; germination of urediniospores of these two fungi during and after exposure to these fungicides was similar. Two interesting fungus-fungicide interactions were apparent (Table 3). Fenhexamid was particularly toxic to urediniospores of $P$. pelargonii-zonalis during exposure; germination was only $0.6 \%$, while it was at least $21 \%$ for all other rust fungi. Also, iprodione was particularly toxic to urediniospores of $P$. oxalis; these spores did not germinate either during or after exposure to this fungicide, while urediniospores of all other pathogens had a minimum germination of $33.9 \%$ after exposure (Fig. 1).

When spore germination was assessed during direct exposure to fungicideamended PDA, responses of individual rust fungi usually were consistent (Table 3, Fig. 1). All 12 fungicides significantly reduced spore germination, but the broad-spectrum fungicides, strobilurins, and copper were significantly more effective than were the DMI, benzimidazole, dicarboximide, and hydroxyanalide compounds. There were no differences in efficacy among the broad-spectrum fungicides, strobilurins, and copper. However, there were significant differences in efficacy among the DMI, benzimidazole, dicarboximide, and hydroxyanalide compounds. The four DMIs were more effective than the three other compounds at inhibiting germination, and the benzimidazole (thiophanatemethyl) and dicarboximide (iprodione) fungicides usually were more effective than the hydroxyanalide compound (fenhexamid). The effectiveness of the DMI, benzimidazole, and dicarboximide products varied among the six rust fungi.

When spore germination was assessed after exposure to fungicide-amended agar, results similar to those reported above for germination during exposure occurred with the following exceptions (Table 3, Fig. 1). The four DMIs and the three other compounds (thiophanate-methyl, iprodione, and fenhexamid) varied in efficacy, but the DMIs were not always more effective. The benzimidazole, dicarboximide, hydroxyanalide fungicides varied in efficacy among the six rust fungi. The effectiveness of the DMI products varied among the six rust fungi, except that there was no difference among triazole compounds.

Experiment 2: Effect of exposure time on toxicity. Germination was affected differentially when urediniospores of $P$. pelargonii-zonalis were exposed to five fungicides for different lengths of time. In a two-way ANOVA, the fungicide $\times$ time interaction was highly significant $(P<$ $0.0001)$. Over the duration of this experiment, the effects of trifloxystrobin and 
chlorothalonil were similar, and the effects of mancozeb, azoxystrobin, and copper sulfate pentahydrate were similar (Fig. 2). Therefore, these data were re-analyzed in two separate two-way ANOVAs-one comparing trifloxystrobin and chlorothalonil over time and one comparing mancozeb, azoxystrobin, and copper sulfate pentahydrate over time.

In the ANOVA for trifloxystrobin and chlorothalonil, the effects of fungicides and the fungicide $\times$ time interaction were not significant $(P=0.993$ and $P=0.343$, respectively), but the effect of exposure time was significant $(P<0.0001)$. Therefore, the effect of exposure time on germination was determined for the two fungicides combined (Fig. 2). Germination of spores exposed to chlorothalonil and trifloxystrobin decreased as exposure time increased and was completely inhibited after 4 and $8 \mathrm{~h}$ of exposure to trifloxystrobin and chlorothalonil, respectively. In the ANOVA for the three fungicides, the effects of fungicides were not significant $(P=0.062)$, but the effects of exposure time and the fungicide $\times$ time interaction were significant $(P<0.001$ and $P=0.014$, respectively). However, this interaction was due to the significantly lower germination at $1 \mathrm{~min}$ of spores exposed to mancozeb compared with those exposed to azoxystrobin and copper. Spore germination percentages at all other time intervals were nearly identical for the three fungicides, so the effect of exposure time on spore germination was determined for these three fungicides combined (Fig. 2). For spores exposed to azoxystrobin, copper sulfate pentahydrate, and mancozeb, germination decreased dramatically after exposure for only $1 \mathrm{~min}(18,18$, and $7 \%$, respectively) and was inhibited almost completely after exposure for $30 \mathrm{~min}(3$, $<1$, and $<1 \%$, respectively) (Fig. 2).

Experiment 3: Toxicity of fungicides to germinated spores. In this experiment, urediniospores of $P$. hemerocallidis, $P$. pelargonii-zonalis, and $P$. iridis were allowed to initiate germination on filters placed on water agar before being placed on fungicide-amended PDA. For the baseline germination and germ tube length, urediniospores were measured after $4 \mathrm{~h}$ in the dark on WA. For $P$. hemerocallidis, $P$. pelargonii-zonalis, and $P$. iridis, germination of urediniospores was 9.6, 8.0, and $5.9 \%$, and average germ tube lengths were 36,12 , and $6 \mu \mathrm{m}$, respectively. After urediniospores were transferred to each of the fungicide-amended PDA plates for $24 \mathrm{~h}$ and then washed off, there was no further significant germination or germ tube growth for each of the pathogens (data not shown). There also was no significant increase in percent germination and germ tube growth among the five fungicides for each rust fungus. The percentage of urediniospores not exposed to fungicides that germinated after $24 \mathrm{~h}$ in the dark and lengths of germ tubes that subsequently developed were $77.1 \%$ and $312 \mu \mathrm{m}$ for $P$.

Table 3. Germination of urediniospores of each of six rust fungi not exposed to fungicides (control) and during or after exposure to 12 fungicides for $24 \mathrm{~h}$ : $P$ $>F$ values from two-way analyses of variance (ANOVAs) for main effects of fungicides, exposure type, and the fungicide $\times$ exposure interaction and from one-way ANOVAs for 12 single-degree-of-freedom contrasts comparing fungicides for each type of exposure

\begin{tabular}{|c|c|c|c|c|c|c|}
\hline \multirow[b]{2}{*}{ ANOVA source of variation } & \multicolumn{6}{|c|}{ Host plant of rust fungus } \\
\hline & Daylily & Geranium & Iris & Azalea & Wood-sorrel & Spearmint \\
\hline \multicolumn{7}{|l|}{ Two-way ANOVA main effects } \\
\hline Fungicides & $<0.001$ & $<0.001$ & $<0.001$ & $<0.001$ & $<0.001$ & $<0.001$ \\
\hline Exposure type & $<0.001$ & $<0.001$ & $<0.001$ & $<0.001$ & $<0.001$ & $<0.001$ \\
\hline Fungicide $\times$ exposure interaction & $<0.001$ & $<0.001$ & $<0.001$ & 0.002 & $<0.001$ & $<0.001$ \\
\hline \multicolumn{7}{|l|}{ One-way ANOVA contrasts: During fungicide exposure ${ }^{\mathrm{z}}$} \\
\hline 12 fungicides vs. control & $<0.001$ & $<0.001$ & $<0.001$ & $<0.001$ & $<0.001$ & $<0.001$ \\
\hline $\begin{array}{l}(\text { Broad }+ \text { strob }+ \text { cop }) \text { vs. }(\text { DMIs }+ \text { benz }+ \text { dicarb }+ \\
\text { hydroxy })\end{array}$ & $<0.001$ & $<0.001$ & $<0.001$ & $<0.001$ & $<0.001$ & $<0.001$ \\
\hline (Broad-spectrums + copper) vs. strobilurins & 0.930 & 0.938 & 0.960 & 0.829 & 0.971 & 0.697 \\
\hline Broad-spectrum vs. copper & 0.962 & 0.902 & 0.986 & 0.371 & 1.000 & 0.992 \\
\hline $\begin{array}{l}\text { Between broad-spectrums: mancozeb vs. } \\
\text { chlorothalonil }\end{array}$ & 0.861 & 0.960 & 1.000 & 1.000 & 1.000 & 0.987 \\
\hline $\begin{array}{l}\text { Between strobilurins: azoxystrobin vs. } \\
\text { trifloxystrobin }\end{array}$ & 0.953 & 0.959 & 0.955 & 0.421 & 0.961 & 0.612 \\
\hline (Benz + dicarb + hydroxy) vs. DMIs & $<0.001$ & $<0.001$ & $<0.001$ & 0.001 & $<0.001$ & 0.009 \\
\hline (Benz + dicarb) vs. hydroxyanilide & $<0.001$ & 0.762 & 0.001 & $<0.001$ & $<0.001$ & $<0.001$ \\
\hline Benzimidazole vs. dicarboximide & 0.001 & 0.911 & $<0.001$ & $<0.001$ & 0.300 & 0.548 \\
\hline Among DMIs: DMI-triazoles vs. DMI-imidazole & 0.619 & $<0.001$ & 0.002 & 0.885 & 0.970 & 0.157 \\
\hline $\begin{array}{l}\text { Among triazoles: triadimefon vs. (myclobutanil + } \\
\text { propiconazole) }\end{array}$ & 0.023 & $<0.001$ & 0.018 & 0.027 & 0.692 & 0.234 \\
\hline Myclobutanil vs. propiconazole & $<0.001$ & $<0.001$ & 0.003 & 0.277 & 0.970 & $<0.001$ \\
\hline \multicolumn{7}{|l|}{ One-way ANOVA contrasts: After fungicide exposure ${ }^{\mathrm{z}}$} \\
\hline 12 fungicides vs. control & $<0.001$ & $<0.001$ & $<0.001$ & $<0.001$ & $<0.001$ & $<0.001$ \\
\hline $\begin{array}{l}(\text { Broad }+ \text { strob }+ \text { cop }) \text { vs. }(\text { DMIs }+ \text { benz }+ \text { dicarb }+ \\
\text { hydroxy })\end{array}$ & $<0.001$ & $<0.001$ & $<0.001$ & $<0.001$ & $<0.001$ & $<0.001$ \\
\hline (Broad-spectrums + copper) vs. strobilurins & 0.875 & 0.696 & 0.421 & 0.846 & 0.981 & 0.472 \\
\hline Broad-spectrum vs. copper & 0.956 & 0.313 & 1.000 & 0.933 & 0.993 & 0.581 \\
\hline $\begin{array}{l}\text { Between broad-spectrums: mancozeb vs. } \\
\text { chlorothalonil }\end{array}$ & 0.920 & 1.000 & 1.000 & 1.000 & 0.988 & 1.000 \\
\hline $\begin{array}{l}\text { Between strobilurins: azoxystrobin vs. } \\
\text { trifloxystrobin }\end{array}$ & 0.981 & 0.963 & 0.284 & 0.770 & 0.983 & 0.194 \\
\hline (Benz + dicarb + hydroxy) vs. DMIs & $<0.001$ & $<0.001$ & $<0.001$ & 0.001 & $<0.001$ & 0.147 \\
\hline (Benz + dicarb) vs. hydroxyanilide & 0.032 & 0.377 & 0.347 & 0.913 & $<0.001$ & $<0.001$ \\
\hline Benzimidazole vs. dicarboximide & $<0.001$ & 0.001 & $<0.001$ & 0.414 & $<0.001$ & 0.002 \\
\hline Among DMIs: DMI-triazoles vs. DMI-imidazole & $<0.001$ & 0.869 & 0.006 & 0.154 & 0.146 & 0.333 \\
\hline $\begin{array}{l}\text { Among triazoles: triadimefon vs. (myclobutanil + } \\
\text { propiconazole) }\end{array}$ & 0.096 & 0.882 & 0.147 & 0.184 & 0.897 & 0.144 \\
\hline Myclobutanil vs. propiconazole & 0.001 & 0.854 & 0.136 & 0.003 & $<0.001$ & 0.552 \\
\hline
\end{tabular}

${ }^{y}$ Germination of urediniospores was evaluated while spores were exposed directly to fungicide-amended medium (during exposure) or after spores were removed from the fungicide-amended medium and rinsed free of fungicide residues (after exposure); data are plotted in Figure 1.

${ }^{\mathrm{z}}$ Abbreviations of fungicide categories: Broad $=$ broad-spectrum, strob $=$ strobilurins, DMI $=$ demethylation inhibitor, cop $=$ inorganic copper, benz $=$ benzimidazole, dicarb $=$ dicarboximide, hydroxyl $=$ hydroxyanalide. 
hemerocallidis, $77.2 \%$ and $209 \mu \mathrm{m}$ for $P$. pelargonii-zonalis, and $71.5 \%$ and $215 \mu \mathrm{m}$ for $P$. iridis.

Experiment 4: Pathogenic potential of spores after exposure to fungicides. Eight of the fungicides were tested in the final study using $P$. pelargonii-zonalis and geranium seedlings. All eight fungicides significantly reduced urediniospore germination compared with the nontreated control treatment (Table 4). However, the broad-spectrum protectants (mancozeb and chlorothalonil), azoxystrobin, and copper sulfate pentahydrate were significantly more effective than the three DMI fungicides and iprodione-as in previous experiments. Germination with the four most effective compounds was less than $1 \%$ but with the other four compounds was at least $28 \%$. Likewise, geranium seedlings inoculated with urediniospores exposed to mancozeb, chlorothalonil, azoxystrobin, or copper sulfate pentahydrate had the least numbers of lesions $(<1)$, but plants inoculated with spores exposed to propiconizole and triadimefon had lesion numbers that were not significantly different (25 and 65 , respectively) (Table 4). Seedlings inoculated with spores previously exposed to myclobutanil and iprodione had just as many lesions as seedlings inoculated with

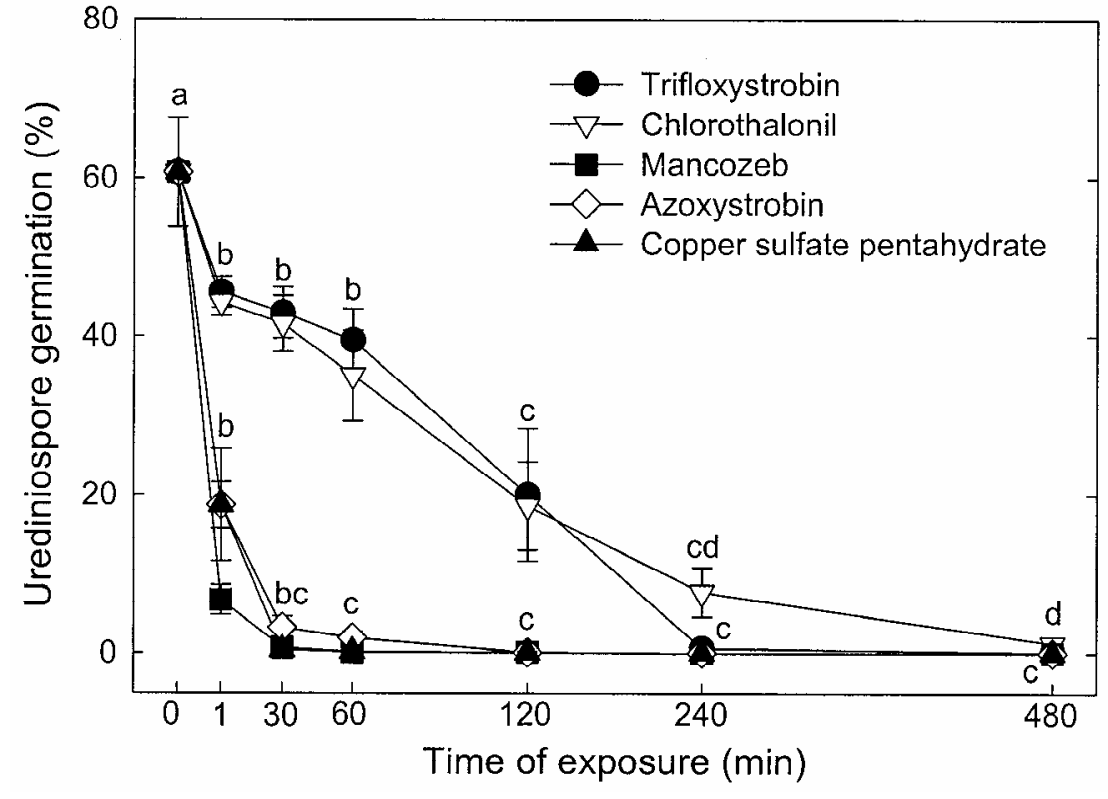

Fig. 2. Germination of urediniospores of Puccinia pelargonii-zonalis after exposure to azoxystrobin, trifloxystrobin, chlorothalonil, mancozeb, or copper sulfate pentahydrate in fungicide-amended potato dextrose agar over time. Data are means calculated from three replications in each of two trials with at least 150 urediniospores assessed per replicate; error bars are standard deviations. Data were analyzed by two-way analysis of variance, but those for trifloxystrobin and chlorothalonil were analyzed independently from those for mancozeb, azoxystrobin, and copper sulfate pentahydrate because of an interaction between the two groups of fungicides. There was no difference among fungicides within each set of fungicides. Means for each set of fungicides over time without a letter in common are significantly different (Fishers least significant difference, $P=0.05$ ).

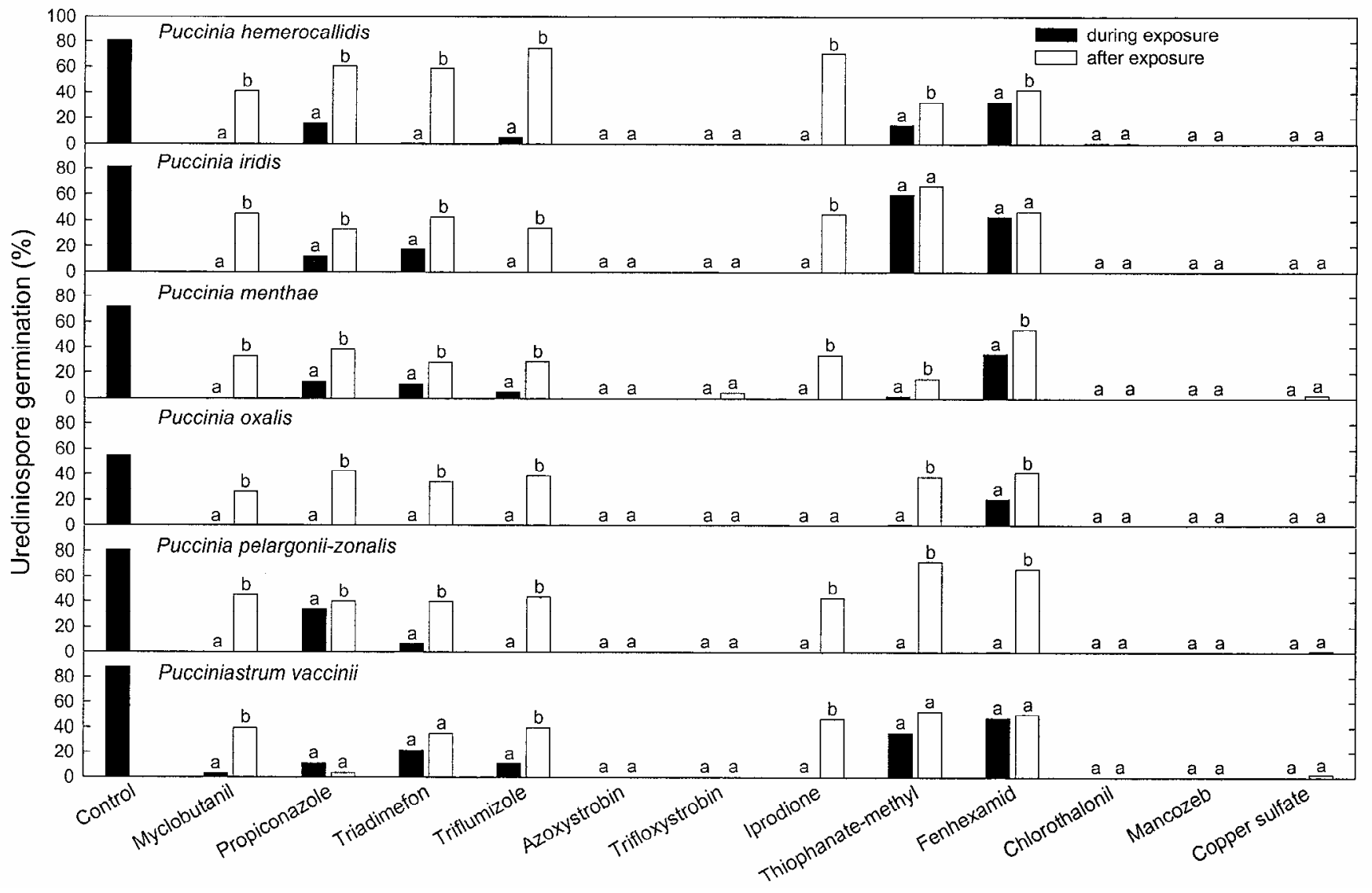

Fig. 1. Germination on agar of urediniospores of six rust fungi not exposed to fungicides (control) and during and after exposure to 12 fungicides added to the agar medium. Germination during exposure was assessed while spores were on fungicide-amended potato dextrose agar (PDA). Germination after exposure was assessed when spores that had been exposed to fungicide-amended PDA for $24 \mathrm{~h}$ were removed from the medium, washed free of fungicide residues, and incubated on PDA amended with chloramphenicol (CPDA). Germination in control treatments was assessed on CPDA. Data are means of three replicates in each of two trials with at least 150 urediniospores assessed per replicate. 
spores not exposed to fungicides (Table 4). There was a significant positive correlation between percent germination of fungicideexposed urediniospores and numbers of lesions that developed on seedlings inoculated with these spores $(r=0.81, P<$ $0.0001)$. In addition, there was a significant positive correlation between germination of urediniospores that were exposed to fungicides by spray in this experiment and in PDA from experiment $1(r=0.80, P<$ 0.0001).

\section{DISCUSSION}

In this study, we examined the toxicity of 12 commercially available fungicides to urediniospores of six rust fungi that occur on ornamental crops-i.e., five species of Puccinia and one species of Pucciniastrum. Five of these fungicides- the two strobilurins (azoxystrobin and trifloxystrobin), the two broad-spectrum protectants (chlorothalonil and mancozeb), and the inorganic copper compound (copper sulfate pentahydrate)—were fungicidal and killed urediniospores of all six pathogens. In addition, urediniospores of $P$. pelargonii-zonalis that were exposed to four of these fungicides-azoxystrobin, chlorothalonil, mancozeb, and copper sulfate pentahydrate-for $48 \mathrm{~h}$ were unable to infect geranium seedlings; trifloxystrobin was not evaluated in this experiment. These five fungicides were more toxic to urediniospores of rust fungi than were the benzimidazole (thiophanate-methyl), dicarboximide (iprodione), hydroxyanilide (fenhexamid), and DMI (myclobutanil, propiconazole, triadimefon, and triflumizole) fungicides that we evaluated. The activity of the seven fungicides that were less toxic appeared to be more fungistatic than fungicidal. However, it is important to note that fungicides that are fungicidal as well as those that are fungistatic to urediniospores have effectively managed rusts on ornamental crops in nursery and greenhouse studies $(3,4,8,11,12,15,17-19,23)$.

Table 4. Germination on agar and the number of lesions that developed on geranium seedlings inoculated with urediniospores of Puccinia pelargonii-zonalis after exposure to fungicides for $48 \mathrm{~h}^{\mathrm{x}}$

\begin{tabular}{lcc}
\hline Fungicide & Germination $(\%)^{\mathbf{y}}$ & Lesions/seedling (no.) $)^{\mathbf{y}}$ \\
\hline Control & $51.4 \mathrm{a}$ & $148.0 \mathrm{a}$ \\
Iprodione & $38.0 \mathrm{~b}$ & $146.7 \mathrm{a}$ \\
Triadimefon & $30.5 \mathrm{~b}$ & $64.8 \mathrm{bc}$ \\
Myclobutanil & $29.3 \mathrm{~b}$ & $81.2 \mathrm{ab}$ \\
Propiconazole & $28.8 \mathrm{~b}$ & $25.2 \mathrm{bc}$ \\
Copper sulfate pentahydrate & $0.5 \mathrm{c}$ & $0.3 \mathrm{c}$ \\
Chlorothalonil & $0.5 \mathrm{c}$ & $0.3 \mathrm{c}$ \\
Azoxystrobin & $0.5 \mathrm{c}$ & $0.2 \mathrm{c}$ \\
Mancozeb & $0.1 \mathrm{c}$ & $0.3 \mathrm{c}$ \\
LSD & 9.8 & 78.4 \\
\hline
\end{tabular}

${ }^{\mathrm{x}}$ Spores on filters were treated with fungicides, incubated for $48 \mathrm{~h}$, and washed free of fungicide residues; an aliquot of spore suspension was placed on potato dextrose agar amended with chloramphenicol to assess germination, and the remaining suspension was sprayed on seedlings. Seedlings were placed in a greenhouse for 18 days to allow lesions to develop.

${ }^{y}$ Means of six replicates per treatment in two trials combined with six plants per replicate.

${ }^{z}$ Data were analyzed by one-way analysis of variance, and means were separated with Fishers protected least significant difference (LSD) with $P=0.05$. Means within a column without a letter in common are significantly different.
The five fungicides that were fungicidal to urediniospores presumably were able to penetrate the spore wall and accumulate to a lethal dose. Apparently, azoxystrobin, copper sulfate pentahydrate, and mancozeb quickly entered urediniospores of $P$. pelargonii-zonalis, because significant and dramatic reductions in germination were observed after exposure for only $1 \mathrm{~min}$ and almost no germination was observed after exposure for $30 \mathrm{~min}$ to these fungicides. In contrast, uptake of chlorothalonil and trifloxystrobin into urediniospores took several hours to obtain similar reductions in germination. Each of these fungicides has protectant activity and is considered a potent inhibitor of spore germination $(6,13)$. Azoxystrobin is known to be actively taken up by plant cells and upwardly systemic in plants; therefore, it has very good residual activity and has provided up to 8 weeks of protection from certain plant pathogens (6).

Identifying fungicides that kill quiescent urediniospores on contact serves several purposes. First, these fungicides may be useful in killing spores in open, sporulating uredinia and thereby slowing disease progress in the plant population and the potential development of fungicideresistant isolates. Some fungicides (benzimidazoles, dicarboximides, DMIs, and strobilurins) have specific mechanisms of action that affect only one or a few metabolic sites in target fungi (15). These fungicides are more likely to be associated with the development of resistance in a pathogen population, as has happened with white rust (Puccinia horiana) on chrysanthemum. Fungicides in the carboxamide (benodanil) $(9,11)$, triazole (myclobutanil and propiconazole) $(3,8,17,19)$, and strobilurin (azoxystrobin and kresoximmethyl) (19,23) fungicide classes have provided excellent control of chrysanthemum white rust. However, strains of $P$. horiana eventually were found to have reduced sensitivity to fungicides in each of these classes $(7,9)$. This exemplifies the need for strategic use of fungicides that have a high risk of resistance development in managing rust diseases so that isolates of Puccinia spp. and related fungi remain sensitive to these effective fungicides. Including broad-spectrum protectants such as chlorothalonil, mancozeb, and copper sulfate pentahydrate in a fungicide rotation program has the potential to kill resistant urediniospores, which, in turn, would reduce the potential for survival of fungicide-resistant isolates that may have developed in the pathogen population. Also, the strobilurin fungicides, because of their unique mechanism of action, are effective against pathogens that have developed reduced sensitivity to fungicides in other chemical classes (6).

Compounds with fungicidal activity also may play a role in protecting plants received from locations known to be infested 
with a specific rust pathogen or from a quarantined area. For example, if a shipment of plants originated from an area where a rust is known to occur, applications of one of these fungicides to plants or propagation material soon after arrival could reduce or eliminate quiescent urediniospores that may be present on plant surfaces. Of the five fungicides that killed urediniospores of all six rust fungi, azoxystrobin is the only one that has shown curative properties against species of $P u c$ cinia (18). Therefore, our data suggest that an application of azoxystrobin could target nongerminated, resting urediniospores on plant surfaces as well as provide curative action against urediniospores that already have initiated infection. Other strobilurin fungicides may have similar effects.

These five fungicides also may be useful as fungicide dips or drenches before or immediately after planting or prior to removing plant parts from stock plants for propagation. Bulbs, corms, and other underground plant organs routinely are dipped in fungicides to reduce disease incidence (e.g., 1), and thiophanate-methyl fungicides are labeled for this use. In addition, several fungicides (e.g., thiophanatemethyl, copper sulfate pentahydrate, and captan) have specific label directions for dipping or drenching cuttings of ornamental crops prior to use in propagation. However, none of these label uses for dipping and drenching identify rusts as target pathogens. In 1995, myclobutanil, applied as a spray or a dip, was shown to provide curative activity against $P$. horiana on chrysanthemum cuttings and, since then, has been labeled for this use (Systhane WSP and Eagle 20EW, Dow AgroSciences LLC, Indianapolis, IN). Perhaps similar label recommendations can be developed for the five fungicides that were lethal to urediniospores in this study.

Another potential use of these fungicides would be an application late in the season to reduce survival of urediniospores over the winter. The recent outbreak of daylily rust in the United States has stimulated considerable interest in and questions about this disease, including the potential for inoculum to overwinter. Daylily plant architecture naturally funnels loose urediniospores into the crown of the plant, where spores are protected from environmental extremes and have the potential to overwinter. Because these fungicides are lethal to quiescent urediniospores, applications of these fungicides could reach areas like the crown on daylilies, kill urediniospores, and reduce or eliminate overwintering of potential primary inoculum. Research should be conducted to investigate this possibility.

\section{ACKNOWLEDGMENTS}

We thank M. Case for technical assistance and McCorkle's Nursery in Dearing, GA, for daylily plants.

\section{LITERATURE CITED}

1. Bald, J. G., Paulus, A. O., and Lenz, J. V. 1973. Fungicidal dips for Easter lily bulbs treatment before shipment. Calif. Agric. 27:8-10.

2. Bhowmik, T. P., and Singh, A. 1979. Evaluation of certain fungitoxicants for the control of sunflower rust. Indian Phytopathol. 32:443-444.

3. Bonde, M. R., Peterson, G. L., Rizvi, S. A., and Smilanick, J. L. 1995. Myclobutanil as a curative agent for chrysanthemum white rust. Plant Dis. 79:500-505.

4. Buck, J. W., and Williams-Woodward, J. L. 2003. The effect of fungicides on urediniospore germination and disease development of daylily rust. Crop Prot. 22:135-140.

5. Cabral, S. M. J. C. S., and Cabral, J. P. S. 1995. The fungistatic and fungicidal activity of vinclozolin against Botrytis cinerea. Mycol. Res. 99:1041-1046.

6. Clough, J. M., and Godfrey, C. R. A. 1998. The strobilurin fungicides. Pages 109-148 in: Fungicidal Activity Chemical and Biological Approaches to Plant Protection. D. Hutson and J. Miyamoto, eds. John Wiley \& Sons Ltd., West Sussex, England.

7. Cook, R. T. A. 2001. First report in England of changes in the susceptibility of Puccinia horiana, the cause of chrysanthemum white rust, to triazole and strobilurin fungicides. Plant Pathol. 50:792.

8. Dickens, J. S. W. 1990. Studies on the chemical control of chrysanthemum white rust caused by Puccinia horiana. Plant Pathol. 39:434-442.

9. Dirkse, F. B., Dil, M., Linders, R., and Rietstra, I. 1982. Resistance in white rust (Puccinia horiana P. Hennings) of chrysanthemum to oxycarboxin and benodanil in the Netherlands. Meded. Fac. Landbouwwet. Rijksuniv. Gent 47:793-800.

10. Dreistadt, S. H. 2001. Integrated Pest Man- agement for Floriculture and Nurseries. Publ. 3402. Regents of the University of California, Division of Agriculture and Natural Resources, Oakland.

11. Gjaerum, H. B. 1979. Rustsopper pa veksthuskulturer (Translated: Rust fungi on glasshouse crops). Forsk. Fors. Landbruket. 30:91-109.

12. Harwood, C. A., and Raabe, R. D. 1979. The disease cycle and control of geranium rust. Phytopathology 69:923-927.

13. Hewitt, H. G. 1998. Fungicides in Crop Protection. CAB International, New York.

14. Hisada, Y., and Kawase, Y. 1977. Morphological studies of antifungal action of $\mathrm{N}-\left(3^{\prime} 5^{\prime}\right.$ dichlorophenyl)-1,2-dimethylcyclopropane1,2'-dicarboximide on Botrytis cinerea. Ann. Phytopathol. Soc. Jpn. 43:151-158.

15. Jeffers, S. N., Miller, R. W., and Powell, C. C. 2001. Fungicides for ornamental crops in the nursery. Pages 409-416 in: Diseases of Woody Ornamentals and Trees in Nurseries. R. K. Jones and D. M. Benson, eds. American Phytopathological Society, St. Paul, MN.

16. Jones, R. K., Simone, G. W., von Broembsen, S. L., and Dutky, E. Integrated disease management. Pages 376-383 in: Diseases of Woody Ornamentals and Trees in Nurseries. R. K. Jones and D. M. Benson, eds. American Phytopathological Society, St. Paul, MN.

17. Lam, C. H., and Lim, T. K. 1993. Efficacy of hexaconazole for the control of white rust on chrysanthemum and powdery mildew on roses. Int. J. Pest Manag. 39:156-160.

18. Mueller, D. S., Jeffers, S. N., and Buck, J. W. 2004. Effect of timing of fungicide applications on development of rusts on daylily, geranium, and sunflower. Plant Dis. 88:657-661.

19. O'Neill, T. M., and Pye, D. 1997. Evaluation of fungicides for control of chrysanthemum white rust (Puccinia horiana). Ann. Appl Biol. (Suppl.) 18:8-9.

20. Reuveni, M., and Sheglov, D. 2002. Effects of azoxystrobin, difenoconazole, polyoxin B (polar) and trifloxystrobin on germination and growth of Alternaria alternata and decay in red delicious apple fruit. Crop Prot. 21:951955.

21. Stebbins, T., and Johnson, D. 2001. Regulatory control. Pages 457-458 in: Diseases of Woody Ornamentals and Trees in Nurseries. R. K. Jones and D. M. Benson, eds. American Phytopathological Society, St. Paul, MN.

22. U.S. Dep. Agric., Animal Plant Health Inspection Serv. 2003. APHIS Regulated Pest List U.S. Dep. Agric., APHIS. Online publication.

23. Wojdyyla, A. T., and Orlikowski, L. B. 1999 Strobilurin compounds in control of rust, powdery mildew and black spot on some ornamental plants. Meded. Fac. Landbouwkund. Toegepaste Biol. Wetenschappen Univ. Gent 64:539-545. 